\title{
Certification of civil society institutes: international tendency and Uzbekistan education
}

\begin{abstract}
This article analyzes the theory of civil society, its emergence and developmen trends. Civil society is a social phenomenon that is rapidly developing with such criteria as democracy, human rights, freedom of speech and conscience, free market economy. In this regard, in Uzbekistan, the processes of democratic governance and the formation of a strong civil society are gradually being implemented in recent years. The scientific article presents the results of scientific research on the formation, development and prospects of non-governmental non-profit organizations in the Uzbek society. In particular, the formation of a civil society in the country is divided into four stages, and its specific features are given a scientific analysis. As a result of the article, recommendations and conclusions on the formation of a strong civil society in Uzbekistan are presented.
\end{abstract}

Keywords: civil, society, Uzbekistan, non-governmental, non-profit organizations, democratic governance, strong

\section{Introduction}

Civil society is a historical phenomenon reflected by its specific institutions, formed at a certain stage of the development of the social and political thinking of individuals and societies and has undergone several social, political, ideological transformation processes. Studying the process of formation and development of civil society institutions, in turn, plays an important role in the study of the socio-political nature of these institutions, which are an important component of civil society. Institutionalization of civil society began in the antiquity, and today its spiritual and ideological components are being improved and perfected. In ancient Greece, the activity of the population or citizens was primarily determined by their participation in the kale yard (city-state) affairs. ${ }^{1}$ They have shaped and acted in different associations based on their interests, civic and political positions.

\section{Methods of research}

In the implementation of scientific research mainly applied general theoretical and empirical methods - systemic, structural and institutional, widely used in the socio-political sciences. A comparative analysis of the development of civil society institutions has been made. In addition, the scientific-theoretical and factual base of NGOs in Uzbekistan was collected and analyzed.

\section{Discussion}

Of course, the ancient world did not ignore the problem of humanity and society while studying the science of the universe. For example, thinking of an ideal state system in his views, Plato suggested that all social obligations in that country were equally distributed. According to Plato, the state should not act contrary to public life but must support it in every possible way. ${ }^{2}$ He paid great attention to the institution of the family and interpreted the family as the primary part of society. Family education emphasizes a serious impact on the social, political and ideological viewpoints of a person in his later life and positively.

From this point of view, it can be argued that Aristotle's claim that "the state is an independent set of self-helping citizens" can actually be regarded as the basis of the concept of civil society. ${ }^{3}$ Aristotle is one
Volume 3 Issue I - 2019

\author{
Salaev Dilshod Jumanazarovich \\ Senior Scientific Researcher, Uzbekistan State World Languages \\ University, Uzbekistan
}

Correspondence: Salaev Dilshod Jumanazarovich, Senior Scientific Researcher, PhD student of the Uzbekistan State World Languages University, Tashkent, Uzbekistan, Tel +9989| 42297 74, Email s.saidov.uz@gmail.com

Received: January 05, 2019 | Published: February 20, 2019 of the first to call for legislative, executive, and judicial powers in the country, and to act legally in society. Although there are no political parties in the political life of antiquity, we can see that in the VIIVI centuries $A D$ there were formed special political groups and they acted as specific political institutions representing the interests of the Attic aristocracy. In the fifth century BC, Athens formed a secret team against the oligarchs' building of democracy (Geterian). At the same time, in the 12 tables of Romans, there is a mass-legal board. They existed in two forms: religious and trade unions, mostly in the form of handicraft shops, poor charities, trade unions and other organizations. In the Middle Ages, the Guilds (Traders and Craftsmen) unions acted as public organizations. ${ }^{4}$ The formation and functioning of civil society institutions in the country are closely linked to the governance system, the political regime, and the civil culture. The most advanced forms of civil society can be said to have grown from democracy, embracing the system of self-government and self-governance.

The modern interpretation of civil society is based on European political traditions and is based on institutions that are vital in the human societies and in the socio-economic, social and spiritual processes of society. The political aspects of civil society institutions are based primarily on the ideology of human beings and their interests and help them to exercise their rights and freedoms in society. It should be noted that today, in the definition of civil society, two different approaches can be distinguished.

1) The Geterogen approach is a system of civil society that is opposed to the state, that is, the entire system, except for the state system (power, politics, bureaucracy, etc.)

2) Existential approach is perceived by civil society as the most important factor for market economy and democracy.

Civil society is primarily based on the social partnership between the state and the society, emphasizing the institutionalization of social relationships, values, interests and needs. ${ }^{5}$

Accordingly, the civil society can be considered as a separate circle of societies that are in opposition to the state and, in turn, connected with it in many fields. Civil society institutions ensure the integration of personal and public interests, fulfilling their own "mediation" function between the individual and the state. Thus, the civil society is 
implementing its legal, institutionalized institutions that independently implement its socio-political and socio-economic interests. Collaboration between government and civil society institutions may be based on compromise, mutual support, or competitiveness based on contradictions and conflicts. Such multilateral relationships exist within the civil society among its various institutions. This dialectic, which is rich in serious and contradictory ideas based on the diversity of institutions, pluralism of ideas and ideas, is essentially important in the development of effective democracy in the country. The ideological and institutional weakening of civil society leads to the emergence of authoritarian tendencies in public administration and to the quasi-democracy, political and social tensions that emerge in society, and quasi-democracy. ${ }^{6}$

The researchers have the practice of dividing the history of the formation of modern civil society institutions into four dimensions in countries around the world. The first stage - the period from the mid19th century to the first world war; the second stage - the historical period between the two world wars; the third stage - from the Second World War to the 90s of the XX century; and the fourth stage - from the 90 s to the present day.

Civil society institutes have stepped up these stages, and at different times of political history, they were enriched with new facets and edges. Many of the factors that led to the emergence of these new social associations were:

a) Formation and development of central government in many countries of the world;

b) The rise of public opinion and culture of the people in these countries;

c) The difficulty of covering all aspects of the society by the state and the increased need for strong civil society;

d) Traditional methods of governance and public administration, and so on.

Public associations accomplish various missions and replenish many of the government's weaknesses. They promote social, political, cultural, and ideological support of the population and the formation of a person as an active citizen. The description of $\mathrm{R}$. Terner and L. Killian in public associations is also remarkable. They say, "Community associations and social movements are a long-term activity that is a collective body that seeks to help (or oppose) social change in the community". ${ }^{8}$

In order to fully analyze civil society institutions, it is important to first investigate all elements of the civil society. In civilized countries, as a component of civil society:
1) a person
2) family
3) school
4) Religious associations (mosques, churches, etc.)
5) personal property and entrepreneurship
6) social group, layers, and classes
7) privacy and guarantees of citizens
8) democratic institutions
9) public organizations, political parties and movements

10) the justice system

11) the education and training system

12) independent media

13) Non-governmental socio-economic relations and others.

Integration and effective functioning of these sectors of society's life will, in turn, lead to the formation of a strong civil society, the rule of law, and the development of a free market economy. It is a worthy contribution to the development of the state while maintaining balance in interests and equality of interests. The primary and fundamental element of civil society is primarily a person, and the social institutions founded on the basis of it. Civil society ensures participation of the individual in one or another type of associations, based on their interests and needs. While civil society institutions play a key role in this regard, they are the key to solving common problems, ensuring and protecting their own needs and interests in politics, economy, culture, and social life. ${ }^{9}$

Civil society institutions can be classified to provide an effective and thorough study of civil society institutions and their participation in government and public life:

a) civil society institutions working in the field of protection of the rights and interests of citizens - advocacy, human rights organizations, notaries and others;

b) civil society institutions operating in the political sphere-political parties and movements;

c) civil society institutions operating in the socio-economic, cultural and educational spheres - nongovernmental non-commercial organizations (NGOs), public funds, associations, trade unions, mass media, citizens' self-governing bodies.

It should be noted that the building of a democratic state and civil society is an important basis not only for the domestic political needs but also for the development of the country at the global level. In spite of the diversity of the world, it is unique in one aspect; that is to say, the main resource of civilization is to achieve literally progressthe broader and more productive opportunities for the human being. In this context, the relationship between government and civil society is an important indicator of democracy. The formation of a mechanism for effective communication between public authorities and the public authorities is the key to the development of democracy, limiting authoritarianism in society and government. Civil society is primarily responsible for social responsibility and activity. Just as civilians can be social, politically, economically active and participate in various non-governmental organizations and public associations, a strong civil society foundation can be formed. In this regard, the role of non-governmental non-profit organizations is also crucial for organizations that unite people for a common purpose and aspiration, and increase their involvement and activism.

In the democratic countries, the state recognizes the role and importance of NGOs. NGOs are working on an equal footing with the state to address social problems in society. However, it should be noted that up to the present, the norms of modern international law provide non-governmental non-profit organizations with the single legal definition and classification. In different countries, he has different interpretations. This also creates a challenge not only for methodological inaccuracies in research but also on the regulation of NGOs. ${ }^{10}$ 
In most cases, NGOs are recognized as a non-profit association established on a legally-registered, informal basis by individuals (physical or legal persons) or by groups. Apart from the definition of this definition, it should be noted that it covers aspects that relate to almost all civil society institutions (foundations, associations, charities, institutions, movements, associations, and associations). By the way, NGOs can work, they can be divided into three groups:

1) Non-governmental (international) nongovernmental organizations. They work mainly in many countries of the world and form their own representations (for example, Amnesty International)

2) Regional NGOs. The movement is associated with some parts of the world and includes various associations and individuals (such as the International Censorship Agency (Article XIX)), the headquarters of the London-based Regional Human Rights Organization)

3) National level NGOs, whose activities are carried out at a national level.

As we mentioned above, the third sector and, in general, one of the most important institutions of civil society is the non-profit organization. Initiative and responsible individuals in the community will be able to provide social and legal assistance to the community through their NGO's and to engage in social activities. Although the share of NGOs in different countries is different, it is characterized by many factors, such as social activeness and mobility of people, dissatisfaction in society, democratic freedoms and human rights, and the state's participation in economic life. Particularly, we can observe an integral part of civil society - the developed system of NGOs - in the developed European Union and the United States. The emergence of the first modern non-governmental organizations in these countries is directly related to the character of Protestantism, the formation and development of the market economy, based on the social activity and independence of the individual. On this historic path, Western countries are convinced that the comprehensive support of public organizations and cooperation with them on the basis of law will not only lead to greater socio-economic benefits, but also serve as a basis for strengthening the state system. Also, this system of civil society makes a significant contribution to the open market economy, while balancing the relationship between the producer and the consumer.

Here, the western interpretation of the concept of civil society and non-governmental non-profit organizations is very interesting. For example, US political scientist Michael McFaul said: "The civilian institutions in American have existed for a long time. In practice, they even appeared before the formation of the US government. The immigrants who immigrated to the United States were organized into the first self-governance and public associations. This has led to the establishment of a truly civil society in the future". ${ }^{11}$ In his article titled "Democracy in America," a French political figure, Alexis de Tocqueville, who writes about Americans' lifestyle: "In a few people in the United States, they begin looking for each other, they will unite with each other, as soon as possible. From that time on, they are not alone and realize that they are united by great power and that they can be enlarged". ${ }^{12}$

In the last decade, we can say that the study of civil society is intensifying. Large scientific projects and programs are being implemented in this area. One of them is The Comparative Nonprofit Sector Project, ${ }^{13}$ made by John Hopkins University in the United
States. Its main objective is to study the normative and institutional bases of civil society in the twenty-first century and its integral phenomena in the world.

According to him, the main criteria for non-profit organizations are:

a) availability of an organizational structure

b) working independently of the state

c) the uneven distribution of profit

d) self-governance

e) Voluntary and voluntary membership of the members.

According to experts, the formation of civil society is a complex socio-political, socio-economic and spiritual-ideological process. The role of civil society institutions is crucial. Through them, citizens take an active part in government and society affairs management. In addition, civil society organizations represent the interests of different social groups and contribute to the strengthening of democratic values in the minds of the people, enhancing their political and civic engagement, and extending and deepening the scale of democratic transformations in the country. In addition, the further development of civil society institutions, in particular non-governmental nonprofit organizations, will depend not only on financial support but also on public participation in their lives. In developed countries, nongovernmental nonprofit organizations undertake specific functions of the state and quickly and qualitatively solve existing problems. This is because they have been specializing in years and can quickly and accurately understand what the people want.

The Boston Consulting Group conducted its own research on NGO activities in developed countries. According to him, the share of the "third sector" in GDP is 6.5 percent. The Dutch are ahead. In this country, the NGO's revenues comprise about 15 percent of the gross domestic product. Sergey Perapechka, director of the Moscow office of the company, said that these figures indicate the well-being of non-state organizations in developed countries. In countries where this development is progressing, it is clear that the non-state sector is not developing. Experts point out that in some countries; nonstate non-profit organizations have little or no regard for their place in the country's life. One of the main reasons for this is that, in any country, the NGO first needs the sponsorship of the government, the business sector, and the public. "If the state wants the development of non-profit organizations, then it needs to invest in this direction," says Sergey Perapechka. "For example, in developed countries, the government's funding for NGOs is 48 percent. However, with the financial support of NGOs, good conditions should be created. It should be noted that according to the NGO Sustainability Index, the creation of a robust legal framework in the area, adapting the existing ones to the modern requirements, and the informal coverage of NGO activities has diminished over the past decade. Nevertheless, financial support for countries has improved dramatically. According to experts, the participation of the state in the first stage of development of the NGO is a key element. In particular, due to the state regulation of the state in Croatia, the NGO's index is much higher. According to research, the indicators of the "third sector" in Croatia until 1998 were very low. There was almost no systematic mechanism for supporting NGOs. But this year the centralized financing system has been developed. According to him, funds and other means have been provided through the government's offices of NGOs. Since 
2003, changes have been made to this process and NGOs have been deployed through the ministries. In 2007 the legislation in this area was reformed. Special attention was also paid to the transparency of the sector. An online database of state-funded NGOs has been created. For non-funded areas, the government has adopted a law aimed at attracting volunteers, promoting social responsibility.

It should be noted that the development of civil society institutions serves the development of the country. Therefore, such institutions should be fully supported. In some countries, NGO activities are not adequately addressed. In other words, at the initial stage it was well-supported, and later their support decreased. As a result, the activity of representatives of the "third sector" was overturned and failed to fulfill its purpose fully. In any country, the formation and development of the NGO directly depend on the efficient use of funds. Consequently, some international non-governmental organizations around the world are spending their money on personal needs. First of all, people who trust the NGO will be disappointed. If the public is informed about the spent resources, civil society institutions are advancing in society. So, if the NGO justifies its trust, then it will become a "community engine". Today, the formation of various NGOs and public associations as an integral part of our political and social life is a unique foundation for a strong civil society in our country. A society based on cooperation with government agencies, business networks and the broad community of civil society institutions plays an important role in ensuring the socio-political stability of society. In recent years, significant measures have been taken to increase the role and significance of NGOs and other civil society institutions in the implementation of democratic reforms in all spheres of society and the state. More than 200 normative and legal documents were adopted to improve the effectiveness of non-governmental non-profit organizations; the necessary institutional framework was created to support them.

\section{Conclusion}

It should be noted that the formation of literally civil society is a long and continuous socio-political process. If we look at the retrospective analysis, the formation and development of civil society and its institutional basis in Uzbekistan can be attributed to the following steps:

The first stage, covering the period from 1991 to 2000, has established and strengthened the normative foundations of civil society in Uzbekistan, which laid the foundations for democracy, human rights, liberty and the rule of law. The Constitution of independent Uzbekistan, adopted in 1992, establishes the right of citizens to form and join public associations, trade unions, political parties, and other organizations. In this regard, the Laws of the Republic of Uzbekistan "On Public Associations" (1991), "On Political Parties" (1996), "On Mass Media" (1997), "On Non-Governmental Nonprofit Organizations" (1999) The adoption of the law is a vivid example of our thinking. The second phase focuses on the democratic renewal and modernization of the country, strengthening the independent activities of civil society institutions during the period from 2000 to 2010. The main characteristic of this phase is a gradual transition from a strong state to a strong civil society.

The role of political parties in the governance and public administration has increased. In 2004, the Law of the Republic of Uzbekistan "On Financing of Political Parties" and in 2009 the Constitutional Laws "On Strengthening the Role of Political Parties in Renewal and Further Democratization of Public Administration and Modernization of the Country" should be emphasized. Also, the Joint Resolution of the Legislative Chamber and the Senate of the Oliy Majlis of the Republic of Uzbekistan "On Measures to Strengthen the Support of NGOs and Other Civil Society Institutes" (2008) serves as an important factor in strengthening the activity of civil society institutions in the country. According to the Resolution, the establishment of the Public Fund for Supporting NGOs and other Civil Society Institutions under the Oliy Majlis of the Republic of Uzbekistan was of great importance. The third stage covers the years 2010-2016. This stage of development is primarily connected with the Concept of further deepening of democratic reforms and formation of civil society in the country, put forward by the First President of the Republic of Uzbekistan IA Karimov on November 12, 2010. According to him, the adoption and implementation of the Law of the Republic of Uzbekistan "On Ecological Control”, "On Openness of Public Authorities", "On Social Partnership" and other normative legal acts have become a huge social and political reality.

The fourth phase will continue until 2017. The Strategy is based on the adoption of the Strategy of Action in five priority areas of development of the Republic of Uzbekistan for 2017-2021 and on its basis the process of reforms in all spheres of our society. In the short run, the Nuroniy Fund, the Youth Union, the Council for Farmers, Farmers and Land Owners, the Chamber of Commerce and Industry, the Republican Steering Committee for Coordination of Activities of NGOs, decrees and decisions were made. Adoption of the Decree of the President of the Republic of Uzbekistan on May 4, 2018 "On radically increasing the role of civil society institutions in the process of democratic renewal of the country" was a big step forward in further strengthening the activities of civil society institutions on the basis of the Strategy of Action.

\section{Acknowledgments}

None.

\section{Conflicts of interest}

The author declares that no conflict of interest exists in publishing this article.

\section{References}

1. Slesareva GF. Civil society in the history of European political thought (from antiquity to the first third of the XIX century). Methodology. 2000;10:13-25.

2. Plato Coll. Philosophical heritage. 1994;3:79-420.

3. Aristotle. Nikomakh's ethics. Works: 1984;4:53-120.

4. Yuryev SS. Legal status of public associations. Monograph. 1995.

5. Reznik Yu M. Civil society as a phenomenon of civilization. Part 2. Theoretical and methodological aspects of the study.1998. 29 p.

6. Dudkin AS. The course of lectures on political science. Moscow: MGUPB; 2011. 42 p.

7. Stetsko EV. Non-governmental organizations: the formation of a political brand. Scientific schools of MGIMO; 2010. 109 p.

8. Turner R, Killian L. Collective behavior. NY: Taylor \& Francis; 1972. 308 p.

9. Nersesyants VS. General theory of law and the state: Textbook for high schools. M: Norm; Infra-M; 1999. 18 p. 
10. McFaul M. Civil Society in the United States. Rev Int Organ. 2016;11:361-385.

11. Tocqueville A. Democracy in America. 2000. 142 p.
12. Comparative Nonprofit Sector Project / The Johns Hopkins Center for Civil Society Studies. 1991.

13. The 2016 CSO Sustainability Index for Central and Eastern Europe and Eurasia. 2016. 287 p. 